\author{
Research Article \\ (C) 2022 Samar El Sayad. \\ This is an open access article licensed under the Creative Commons \\ Attribution-NonCommercial 4.o International License \\ (https://creativecommons.org/licenses/by-nc/4.o/)
}

\title{
Delineation of UK Retail Sector: An Actor-Network Perspective ${ }^{1}$
}

\author{
Samar El Sayad \\ Assistant Professor in Accounting, \\ Prince Sultan University, Kingdom of Saudi Arabia; \\ Lecturer in Accounting, Tanta University, Egypt
}

DOI: https://doi.org/10.36941/ajis-2022-0o37

\begin{abstract}
This paper provides a contextual discussion about the UK retail market by screening the relevant literature bodies. The UK retail market is analyzed in terms of its dynamic; the influence market concentration, globalization, and supply chains, and the emerging shifts in the power position. Drawing on ANT, the paper shows how this market comprises a set of networks of various human and non-human actors who interact and negotiate among themselves. It also shows how the power of the UK's big retailers can be regarded as a consequence of these networks and the interrelationship between them.
\end{abstract}

Keywords: Retail Industry, Actor-Network Theory, Supply Chain, Market Concentration, Globalization

\section{Introduction}

Emerging shifts in positions of power from suppliers and manufacturers to retailers, reinforced by market concentration, globalization forces, and the advancement of SC practices, bring us once again to reopen the 'black box' of the UK retail market: we need to rethink how market concentration, SCs, and globalization tendencies can transform the dynamics of the UK retailing market. Consequently, this led the author to reflect on how actors respond to these forces. The author thus approached the UK retail market literature to understand the market dynamics and the key actors involved.

The complexity of the UK retail market can be understood by focusing on the concerns and negotiations among different actors rather than simply focusing only on some technical issues. Thus, I draw on the notion of 'translation' to penetrate the literature to understand how the UK retail market network is constructed and mobilized. By focusing on the 'translation' process, I explore how actors interact and negotiate within the network and the underlying issues and subsequent debates regarding the retail market.

This paper is thus structured as follows: Section 2 provides a brief overview of the development of the UK retail market, and Section 3 presents the notion of 'translation'. Then, Section 4 describes the methodology, while Section 5 analyses the findings, and finally, Section 6 discusses the findings and concludes the paper.

\footnotetext{
${ }^{1}$ This paper is part of my Ph.D. thesis.
} 


\section{UK Retail Market Development: An Overview}

"Any attempt to understand the UK retail scene should start by recognizing the distinctive features of this market" (Burt, Sparks, \& Teller, 2010:174). The UK is one of the world's economic juggernauts, with a population of about 63.7 million in mid-2012 (Statistics, 2013), a GDP of \$2,435,174 million (the world's sixth-largest economy) (Bank, 2013), and the second-highest total consumer expenditure in Europe (Burt et al., 2010). It is a culturally diverse society, with an immigrant population of about $11.4 \%$ (Mulley, 2011) and a minority ethnic population of more than $12 \%$ ("Size of ethnic groups: ONS estimates, 2009," 2009).

According to Jones, Comfort, Hillier, and Eastwood (2005:209), "Retailing is a large, diverse and dynamic sector of the UK economy". The British Retail Consortium estimated in 2011 that the retail sector's contributions to the UK's GDP and total Gross Value Added were $20 \%$ and $11.3 \%$, respectively. It is also the UK's largest private sector employer, with 188 ,ooo retail enterprises providing jobs for around 3 million employees, thus accounting for $10.5 \%$ of the nation's workforce (Consortium, 2012).

Napoleon Bonaparte once referred to the UK as 'a nation of shopkeepers'; nowadays, this description is no longer relevant due to the expansion of the big chain stores and supermarkets at the expense of the traditional outlets, which are vanishing at an alarming rate (Free, 2008). But why is this happening?

The story began in the 1950s when the growth of supermarkets overtook that of independent shops and traditional Co-operative stores (Clarke, 2000). In 1950, the market share of independent shops and Co-operative stores was $80 \%$, while it was $20 \%$ for supermarkets (Blythman, 2004). Since that date, there has been a rapid growth in the number of supermarkets and, as a corollary to this, a sharp decline in the number and market share of independent shops and Co-operative stores (Clarke, 200o). One of the critical factors that have driven this expansion is the conversion from the local counter-service format to self-service format from the late 1940s (Usherwood, 2000); this, in turn, evolved into supermarkets and then stretched again into the development of superstores in the 196os (Thomas, 1991). According to Morelli, "This development of increasingly large scale, high streetbased, supermarket retailing, involving heavy investment in retailing Outlets, continued still further into the 1970s" (Morelli, 1997:775).

The 1970 s was a period of moving toward economies of scale through increasing the size and decreasing the number of the stores: "In one year alone, 1978-79, the multiples closed over 350 shops smaller than 5000 square feet, and opened 60 of more than 10ooo. Over the period 1971-79, the total number of grocery shops fell from 105,283 to 68,567 , a decline of 35 percent; for multiples, the decrease was 45 percent" (Seth \& Randall, 1999:19). The growth rate of superstores was relatively slow during the 1970s, before beginning a period of massive expansion during the 1980 .

The 1980 os have been perceived as the 'golden age' of UK grocery retailing (Burt \& Sparks, 1994); the period was characterized by high levels of concentration, the rise of discount stores, diversification, and the growth of out-of-town retailing. While multiples were dominating the retailing sector before the $198 \mathrm{os}$, that decade witnessed the emergence of a small group of multiples (the 'big five' group comprising J Sainsbury plc, Tesco plc, Asda plc, Argyll Group plc, and Dee Corporation/Gateway plc), who were beginning to rival and dominate the largest companies in any sector in the UK economy (Wrigley, 1993). The dominance and power of this group (big five) increased considerably from one year to the next, and the "combined market share reached $43 \%$ by $1984,58 \%$ by the end of 1988 , and 62\% by 1990" (Wrigley, 1992:729). According to Wrigley (1993:41), "This immense oligopolistic buying power wielded by the retail corporations came to condition all aspects of retailer-supplier relations, and created new corporatist relationships between the retailers and the regulatory state."

Furthermore, the end of the 1980s witnessed the entry of European discount store operators into the UK market, such as the German company Aldi and the Danish company Netto (Burt \& Sparks, 1995). These stores sell limited ranges of products at low prices. According to Guy (1995:26), "Prices were kept low by accepting low margins; by developing cheap 'no-frills' stores in cheap 
locations; and by selling own-brand or 'tertiary brand' goods, which did not carry the promotion and marketing overheads of the top branded goods."

Another critical feature during that period was the strategy of diversification into non-food areas embarked upon by many retailers (Brown, 1990). The food retailers expanded into appliances, books, clothing, and many services, such as financial services, dry cleaning, cafes, and estate agents, to satisfy increasingly demanding customers and increase market share and profitability (Ogbonna, 1989). Gardner and Sheppard (1989:164) argue, "In fact, the non-food area proved increasingly important and partly explains their success in holding on to 38 percent of the total retail turnover when food itself only accounts for 14 percent of consumer expenditure."

The rapid growth of superstores and hypermarkets facilitated offering many non-food products, especially those situated on edge-of-town or out-of-town sites. The growth of out-of-town retailing can be attributed to many factors, including the rapid rise in car ownership; good public transport access, relatively liberal planning regime, the difficulty of finding suitable sites for building superstores or hypermarkets in the city center, increasing rent levels in the town centers compared to out-of-town sites, changes in shopping patterns, and increasing consumer spending power (Jones \& Hillier, 2000). Additionally, the growth of out-of-town retailing increased the operating margin, which jumped to around 6-8\% in 1992 compared with around 3-5\% in the mid-1980s (Guy, 1995).

The development of out-of-town superstores continued into the 1990s. Indeed, in the late 1990s, the number of superstores increased to over 1000 compared to about 450 in the mid-1980s, with stores offering a wide variety of products ranging from groceries to clothes, toys, computers, sports products, and general merchandise (Jones \& Hillier, 200o). The new retail formats, such as retail parks and sub-regional and regional shopping centers, have blossomed (Guy, 1998b). These centers consist of a combination of grocery retailers and several retail warehouses selling clothes, shoes, furniture, and home appliances, often with some fast food outlets, cafes, restaurants, and leisure activities, such as cinemas and bowling alleys (Guy, 1998a; Jones \& Hillier, 2000). However, from the mid-1990s, the new Labour government curbed the development of large superstores by tightening planning regulations and introducing new guidelines under PPG6 and PPG13, instigated by growing public concern about the adverse effects of superstores on the viability of city centers (Pal, Bennison, Clarke, \& Byrom, 2001; Wrigley, 1998). These restrictive regulations triggered a shift in the retailing industry, as big retailers began to focus on the small store format in town and city centers. In 2002, Tesco had 65 'Express' stores (average size 200 sq. meters), Sainsbury's had 18 'Local' stores (average size 280 sq. meters), Asda had 245 stores (average size 4200 sq. meters), and Safeway had 55 'SafewayBP' stores (average size 200 sq. meters) (Dawson, 2004:126).

Then, from the beginning of the 1990 os to the present, it was noted that "the internet is transforming economies and societies, and UK retailers are at the forefront of this change" (Consortium, 2012:38). Big UK retailers were inspired by this innovation and started to embrace online shopping. From the late-1990s to the early-20oos, online shopping was growing at a slow pace due to public concerns regarding site security and because the proportion of users who preferred using the internet for information searches was significantly higher than that of users making purchases using the internet (Fernie, Sparks, \& McKinnon, 2010). However, as the idea took off, online shopping grew quickly, and it is now recognized as the fastest growing area with regard to internet usage (Ellis-Chadwick, Doherty, \& Anastasakis, 2007). Internet sales accounted for about $10 \%$ of total retail sales by the beginning of 2011 (Consortium, 2012). Nowadays, online shopping is becoming increasingly popular and is attaining further widespread acceptance.

This brief overview of the retail market in the UK illuminates various aspects, issues, and norms of behavior that merely reflect the context and that will help to shape our understanding of today's retail marketplace. This paper aims to define the key actors within the UK retail sector and explain the nature of the relationship between these actors through the lens of ANT. The following section will shed light on Actor-Network Theory. 


\section{Actor-Network Theory}

Traditionally, retailers, particularly food retailers, are viewed as the party in the SC responsible for providing a channel between suppliers and end customers (Allan, 1980). From ANT perspective, retailers, and big retailing chains, in particular, become an actor creating an actor-network in which other heterogeneous actors are enrolled and who form alliances in an attempt to legitimize or reject the effect of the focal actor's (i.e., big retailing chain) behavior and actions on other actors in the network.

ANT appeared more than two decades ago in the area of science and technology studies to investigate the development of networks in a scientific research setting, where the focus was mainly the laboratory setting (Williams-Jones \& Graham, 2003). However, over the years, ANT has proved its flexibility to accommodate other fields of studies, such as social sciences, psychology, anthropology, politics, and economics (Lee \& Hassard, 1999). Latour (2003:35) defines ANT as "an argument not about the 'social' but about the associations which allow connections to be made between non-social elements." The central tenet of ANT is that contemporary societies are constituted through heterogeneous networks between human and non-human actors, with aligned interests, and each actor, by itself, is a network (Doolin \& Lowe, 2002). ANT relies on some key concepts, including actors, intermediaries, and networks (Rodger, Moore, \& Newsome, 2009).

According to Latour (2005:46), "An actor in the hyphenated expression actor-network is not the source of an action but the moving target of a vast array of entities swarming toward it". Accordingly, it is any entity (human or non-human) that can act and be acted upon (Callon, 1991). Human actors are shaped by various aspects, including social, political, psychological, economic factors (Latour, 1993). This means that actors are not only nodes within the actor-networks, but are also networks themselves (Law, 1992).

Callon (1991:134) defines intermediaries as "anything passing between actors which defines the relationship between them.” There are four main types of intermediaries as identified by Callon (1991:135):

- texts (literary inscriptions): such as memos, books, reports, articles, graphs, and diagrams

- technical artefacts: such as machines, consumer goods, and scientific instruments

- human beings: such as skills, knowledge, and expertise that they incorporate; it also includes the power and control relationships that shape the action between actors (Comber, Fisher, \& Wadsworth, 2003)

- money in all its different forms

Intermediaries supply the missing link that relates actors to the actor-network and, at the same time, they describe the network. Intermediaries circulate among actors to construct networks, "thus defining the respective position of the actors within the networks and in doing so constituting the actors and the networks themselves" (Powell \& Owen, 2011:147).

Besides actors and intermediaries, 'networks' is another key concept essential to the dynamics of ANT. Callon (1993:263) defines networks as a "group of unspecified relationships among entities of which the nature itself is undetermined." Identifying the interrelationships between the heterogeneous actors, both human and non-human, is of prime importance for understanding any network (Murdoch, Marsden, \& Banks, 200o).

ANT differs from other traditional approaches by advocating a socio-philosophical approach that introduces a symmetrical treatment of human and non-human actors, social and technical factors (McLean \& Hassard, 2004). ANT refuses to draw a distinction between human and nonhuman, social and technical factors or to privilege one over the other factor (Alcadipani \& Hassard, 2010; Bapuji, Hora, \& Saeed, 2012). Law (1991:10) argues that "what appears to be social is partly technical. What we usually call technical is partly social. In practice, nothing is purely technical. Neither is anything purely social."

Actor-networks are characterized by shifting alliances of heterogeneous actors, both human and 
non-human, and instability over time; these necessitate continual maintenance and updating through the enrolment of actors (Williams-Jones \& Graham, 2003). Therefore, it is of particular importance to understand what encourages actors to enroll and engage in a network and what brings the network into being. The answer lies in what Callon and Latour refer to as the 'translation' process, drawing on work by the French philosopher Serres (1974). Callon and Latour (1981:279) explain 'translation' as follows:

By translation, we understand all the negotiations, intrigues, calculations, acts of persuasion and violence, thanks to which an actor or force takes, or causes to be conferred on itself, authority to speak or act on behalf of another actor or force. 'Our interests are the same', 'do what I want', 'you cannot succeed without going through me'.

Then, Latour (1987:108) defines 'translation' as "the interpretation given by the fact-builders of their interests and that of the people they enroll." Every actor enrolled in a network is independent and has their own interests and capable of resistance or accommodation; therefore, the stability of the network is determined by the ongoing translation of these diverse interests (Williams-Jones \& Graham, 2003). According to Callon (1986), the 'translation' process involves four main phases: problematization, interessement, enrolment, and mobilization These are discussed in more detail below.

Problematization refers to actors' efforts to enroll other actors in their own network. This can be achieved by first defining the problem and demonstrating the solution, then defining the attributes and roles of the target actors (Mähring, Holmström, Keil, \& Montealegre, 2004) and enlisting them through a set of well-defined practices (obligatory passage point) that are under the control of the initiating actors (Callon, 1986; Ezzamel, 1994).

During the interessement phase, the initiating actors try to convince the other actors by indicating the defined interests for them and showing that these are, in fact, in line with their own interests. In addition, incentives are created for the actors to cement links between the initiating actors and the other actors (Mähring et al., 2004). Although this phase often involves negotiations among the actors, actors do not usually participate themselves; instead, representatives may participate on their behalf: "In many cases, actors fail to act as promised by their representatives. This phenomenon is referred to as betrayal" (Sarker et al., 2006:55).

Enrolment is the construction of alliances and coalitions between actors within the newly created network (Ezzamel, 1994) through "multilateral negotiations, trials of strength and tricks" (Callon, 1986:211). This phase involves a clear definition of the roles of each actor, which are consistent with the interests of the network, and an agreement among the actors is reached on the ends (Sarker et al., 2006).

The final phase is mobilization. Initiating actors monitor the various interests using a set of methods to ensure that representatives are acting in the interests of their constituents and do not betray the interests of the network (Alcouffe, Berland, \& Levant, 2008). As Mähring et al. (2004:214) put it, "With allies mobilized, an actor-network achieves stability. This stability would mean that the actor-network and its underlying ideas have become institutionalized and are no longer seen as controversial".

At the end of the four phases, a constraining actor-network is constructed; however, Callon (1986) comments that we should be aware that not all networks go through the four phases, as the 'translation' process can be contested at any phase.

One of the main distinguishing features of ANT is that it is "ontologically relativist in that the world may be organized in many different ways" (Lee \& Hassard, 1999:392). Indeed, when researchers embark on research using ANT, they have no clear picture of what sort of actors, intermediaries, or networks they will discover (Lee \& Hassard, 1999). For this, researchers need to follow the actors and understand how they interact together to produce the network under analysis. This is what this paper tries to do. As Latour (1987:258) argues, "We study science in action and not ready-made science or technology; to do so, we either arrive before the facts and machines are black-boxed or we follow the controversies that reopen them" 
This paper aims to reopen the 'black box' of the UK retailing sector and understand the relationships between the actors inside this box.

\section{Research Methodology}

Since the aim of this paper is to reopen the 'black box' of the UK retail market, a thorough scanning of all relevant journals was necessary. The author utilized search keywords such as 'UK retail', 'UK supermarket', 'UK grocery', 'British retail', 'British supermarket', and 'British grocery'. This procedure resulted in a shortlist of 40 papers published in 20 journals. The list of journals and their related papers is displayed in Table 1 . In addition to the journals, it was also necessary to scan some books dealing with the retail sector to achieve my objectives. Thus, five books were chosen (see Table 2).

Table 1: List of journals reviewed

\begin{tabular}{|l|c|}
\hline Journal & No. of Papers \\
\hline International journal of retail and distribution management & 11 \\
\hline British food journal & 7 \\
\hline Accounting, organization, and society & 4 \\
\hline Eco-Management and Auditing & 2 \\
\hline European Journal of Innovation Management & 1 \\
\hline European Journal of Marketing & 1 \\
\hline European Management Journal & 1 \\
\hline European Retail Research & 1 \\
\hline Human Resource Management Journal & 1 \\
\hline International Marketing Review & 1 \\
\hline Journal of Business Research & 1 \\
\hline Journal of Consumer Studies and Home Economies & 1 \\
\hline Journal of Public Affairs & 1 \\
\hline Management Accounting Research & 1 \\
\hline Management Decision & \\
\hline Management Research News & 1 \\
\hline Marketing Intelligence and Planning & \\
\hline Property Management & \\
\hline Supply Chain Management: An International Journal & 1 \\
\hline Total Articles & 1 \\
\hline
\end{tabular}

Table 2: List of books reviewed

\begin{tabular}{|l|l|l|}
\hline Book Title & Authors/Editors & Publisher \\
\hline $\begin{array}{l}\text { The Grocers: The Rise and Rise of the } \\
\text { Supermarket Chains }\end{array}$ & Andrew Seth and Geoffrey Randall & $\begin{array}{l}\text { Kogan Page } \\
\text { Limited }\end{array}$ \\
\hline $\begin{array}{l}\text { The Market Makers: How Retailers are } \\
\text { Reshaping the Global Economy }\end{array}$ & $\begin{array}{l}\text { Gary G. Hamilton, Misha Petrovic, and } \\
\text { Benjamin Senauer }\end{array}$ & $\begin{array}{l}\text { Oxford University } \\
\text { Press }\end{array}$ \\
\hline $\begin{array}{l}\text { Shopped: The Shocking Power of British } \\
\text { Supermarkets }\end{array}$ & Joanna Blythman & Harper Perennial \\
\hline Trolley Wars: the Battle of the Supermarkets & Judi Bevan & Profile Books Ltd \\
\hline Retail Change: Contemporary Issues & $\begin{array}{l}\text { Rosemary D. F. Bromley and Colin J. } \\
\text { Thomas }\end{array}$ & $\begin{array}{l}\text { UCL Press } \\
\text { Limited }\end{array}$ \\
\hline
\end{tabular}




\section{Actor-Network Analysis}

Studying a market was regarded as a key challenge for ANT, as markets provide a clear distinction between human and non-human actors, and the involved actors are characterized by highly demanding competencies, while "ANT was developed to analyze situations in which it is difficult to separate humans and non-humans, and in which the actors have variable forms and competencies" (Callon, 1999:183). However, Callon' responded to this criticism by noting that for market coordinations to succeed, market actors must have "information on all the possible states of the world, on the nature of the actions which can be undertaken and on the consequences of these different actions, once they have been undertaken" (Callon, 1999:184). Therefore, actors should entangle themselves in a network of relations with other actors to get such information. Nonetheless, over the years, the ontological separation between humans and non-humans has been undermined, as markets have become increasingly complex due to several factors, including globalization, technological advancement, and the introduction of new organizational forms, such as SCs and virtual organizations. These factors have led to the enrollment of various social, technical, global, and local actors into the market. Hence, ANT can fit well with the current market ideology.

Drawing on the literature, this paper suggests that the UK retail market can be viewed as a set of networks of various heterogeneous actors, who interact together to form these networks. My review reveals that the UK retail market consists of three key networks, each with different logic and interest:

- market concentration-based network

- supply chain-based network

- globalization-based network

In the following section, I shall draw on the notion of 'translation' to examine the details of the development of the three networks. The aim is to guide researchers to navigate through the large stream of papers in this area of research.

\section{1}

Market Concentration - Based Network

Market concentration has been regarded as a prominent feature of the UK retail market in general and the grocery market in particular (only four major grocery chains: Tesco, Asda, Sainsbury, and Morrisons) (De Kervenoael, Hallsworth, \& Clarke, 2006). "In the last ten years, every third pound is generated by one of the five most powerful players in the market, i.e., Tesco, Sainsbury, Asda, Wm Morrison and Marks and Spencer" (Burt et al., 2010:180). In recent years, market concentration has been attracting increasing attention from academics, the media, politicians, government officials, and other groups. The significance of market concentration and the interest that different entities have in it has brought a consortium of independent actors together to form an actor-network. The main actors showing their interest in market concentration issues are big retailing chains, suppliers and manufacturers, customers, government and regulatory authorities, politicians, academics, the media, and pressure groups.

The starting point here is the big grocery chains. Problematization began when big grocery chains, in their drive for market share, started to change the sector structure by increasing store size and adopting a range of formats in order to reach a large customer base (Hollingsworth, 2004). Consequently, the top four chains (Tesco, Asda, Sainsbury's, Morrisons) now account for about $75 \%$ of the total retail market (Seth \& Randall, 2011). The question that needs to be asked now is whether the concentration of the market in the hands of a small number of players is good or bad for the UK retail market. No clear answer can be given, as while these changes and growth sounded good from the point of view of retailers and other entities, many concerns have been raised regarding the impact of the rapid growth of big retailers on the rest of the retail sector. Several other questions are likely to be raised: Who would participate in this debate? What beliefs have they? What are their interests and 
tasks?

The questions that arise from the practices of big retailers bring other actors directly into the story: suppliers and manufacturers, customers, government and regulatory authorities, politicians, academics, the media, and pressure groups. According to Callon (1986), it is essential to explain how these actors are concerned by the formulated questions:

a. Suppliers and manufacturers: They are highly dependent on big retailers to sell their products and make a profit, as they have moved away from the end customers; hence, there is no relevant alternative distribution channel for their products. However, they are concerned with the impact of the centralization of the buying power and market concentration on their long-term profitability.

b. Customers: They are the beneficiaries of the goods and services provided by the retailers and the ultimate source of money, and so they are the primary deciders on long-term competitiveness (Zairi, 1992). Thus, they are interested in knowing whether they will benefit from market concentration in terms of price, quality, and service (Clarke, 200o).

c. The central government and regulatory authorities: Government intervention in the retail sector has been directed to guaranteeing the pursuit of a free-market economy (Burt et al., 2010), as governments are required to protect other entities from the possible competitive threat posed by the market concentration of retailers (Hamilton \& Petrovic, 2011). In addition, the ability of retailers to grow and to increase their market share depends, to some extent, on securing permissions from local authorities (Clarke, 2000); these authorities should carry out some work and assessment before any permissions can be granted, such as assessing the impact on local shops and communities (Blythman, 2004). Thus, government and regulatory authorities are interested in the formulated question.

d. Politicians: They often consider electoral factors before raising any issue or concerns. As retailers "touch the everyday lives of the vast majority of the population" in the UK (Jones, Comfort, Hillier, \& Eastwood, 2005a), politicians have particular interests in retailing issues.

e. Academics: Academic researchers often are interested in advancing knowledge in any domain of science (Callon, 1986). They are also interested in publishing papers and attending conferences through investigating contemporary issues such as market concentration.

f. Media: The media are a valuable tool for big retailers to add value to their operations, as they can affect consumer behavior. On the other hand, the media often embrace the issues that concern country people. So, the media can be regarded as one of the actors in this network.

g. Pressure groups: Several pressure groups have appeared recently in the UK. They are always concerned with environmental, ethical, and fair trade issues (Strong, 1996). As a result, market concentration is of interest to pressure groups.

The lesson that we can learn here is that assessing the implications of market concentration is the obligatory passage point that satisfies the interests of all actors: "A single question ... is enough to involve a whole series of actors by establishing their identities and the links between them." (Callon, 1986:205)

In the interessement phase, attempts should be made to impose the identities of other actors and persuade them to accept the solution (Murdoch, 1997). Big chains have to convince other actors that concentration serves to increase the competition in the UK market, which, in turn, leads to added value and benefits to customers (Hackney, Grant, \& Birtwistle, 2006). Thus, big chains should concentrate on price and value elements when negotiating with other actors. Inscriptions (in the forms of reports, press releases, and so on) can be used to explain the consequences of concentration. Accounting reports (Frances \& Garnsey, 1996) are of particular interest to big chains, as they use them to support their argument, and so they make these reports publicly available. It has been shown that retailers disclose better and more detailed financial reporting information (Craven \& Marston, 1999). Retailers are also organizing meetings, workshops, and conversations to deliver information to 
other actors.

The third phase is enrolment, which involves a "group of multilateral negations, trials of strength and tricks that accompany the interessements and enable them to succeed" (Callon, 1986:211). The transactions with customers are simple, as they are prepared to believe the big retailers' arguments. The main concerns for customers are price and quality. The retailers place information about the price, features of the products, and available alternatives at a customer's disposal through their websites, media, and other channels. In addition, some retailers choose to list their prices on price comparison websites, such as mysupermarket.com, to allow the customers to compare the prices across retailers. Big retailers can 'get to know the customer' through advanced information systems (e.g., EPOS) on customer buying habits, customer throughput information, and so on (Ogbonna \& Wilkinson, 1998). Thus, they are using such knowledge to tailor their offer to customers in accordance with the data from such information systems.

Many customers believe that when supermarkets offer a price promotion, they must be cutting their profit margin to satisfy their customers and offer them a cheap deal; however, suppliers and manufacturers see matters differently (Blythman, 2004). Big retailers need to convince their suppliers and the manufacturers of their products of the benefits of dealing with large retailers and seeing them as key contributors to their success and long-term profitability. Therefore, big retailers are eager to collaborate with their suppliers and manufacturers by sharing costs and other information. However, in a climate of continued price reduction pressures by big retailers and open-book accounting, many suppliers believe that it is impossible to sustain the prices and attributes as required by retailers (Blythman, 2004). They believe that big retailers are improving their profit margins, through promotions and price cuts, by pushing their costs back onto suppliers and manufacturers (Elms, Canning, Kervenoael, Whysall, \& Hallsworth, 2010; Seth \& Randall, 2011). However, although they may disagree with big retailers' arguments, most suppliers and manufacturers fully understand the nature of the market and are "prepared to adopt a 'swings-androundabouts' approach along the way" as they do not have an adequate negotiating position (Bevan, 2005:179).

Furthermore, transactions with governments and regulatory authorities are not simple; indeed, the retail policy making in UK has been regarded as 'contradictory' (Clarke, 2000). This can be attributed to the "separation of physical store development (dealt with by the town planning system) from the competition (dealt with by central government bodies, such as the office of Fair Trading and the Competition Commission)" (De Kervenoael et al., 2006:388). This separation, in turn, leads to inconsistent policies and opinions. For example, while current planning policies are recognized as a virtual ban on the development of large retailers, other government departments seek to promote competition between retailers and encourage the development of superstores, as this can bring many benefits to customers and prevent a monopoly (Guy \& Bennison, 2002). Big retailers deal with the governments and regulatory authorities in different ways. Town planners try to adjust their attitudes and influence their thinking to get planning permission for new stores (Clarke, 2000). In their endeavor to influence local decision making, retailers benefit from two important points: the reduction in the local authority economic regeneration budget and the concept of 'planning gain', which is recognized by the Town and Country Planning Act 1990 (i.e., section 106 agreements) (Blythman, 2004; De Kervenoael et al., 2006). They bring their resources (i.e., money) to make things happen. For example, in 2000, Tesco won planning permission to build a big store in Coventry after agreeing to partially fund a new sports stadium. For government departments that deal with competition, the situation is different, as they already believe that big retailers play a key role in enhancing retail competition. Therefore, big retailers actively share information and knowledge (e.g., accounting, commercial information, etc.) with these departments to support their arguments.

Big retailers often disclose financial and nonfinancial information about their operations and performance and make it publicly available (e.g., annual reports, press releases, etc.) to persuade everyone that their form of innovation and development is exactly what customers want. However, different entities may interpret this information in different ways. For example, academics raise 
concerns in their papers and articles about the adverse effects of market concentration on small shops and customer choices; these concerns are then picked up by the media and politicians (Burt et al., 2010). In addition, pressure groups, such as Friends of the Earth, the National Federation of Women's Institutes, FARM, and the Association of Convenience Stores, are actively campaigning against the negative effects of market concentration (Jones, Comfort, Hillier, et al., 2005a). Those actors argue that "the market had ceased to operate fairly and that large (food) retailers were making excess profits and abusing their market positions" (Burt et al., 2010:176), and so they petition the government to investigate the situation in the market. These continuing campaigns have brought pressure on the government to give more attention to the practices of big retailers.

Are big retailers able to convince the other actors? This question is crucial to determine whether we can proceed to the last phase. Information and retailers' resources are enough to convince some actors that market concentration is vital for the efficiency of the UK retail market. However, some actors reject this argument and try to influence the attitude of other actors. Hence, big retailers need to deal with this growing controversy and revise the interessement devices. Unless and until agreement among actors is reached, we cannot move to the last phase, i.e., mobilization.

\subsection{Supply Chain - Based Network}

Over the years since its inception, the SC concept has attracted much attention and has helped elucidate many aspects of business markets. Currently, the SC concept is perceived as a common theme in today's highly competitive and uncertain environment, as it can give organizations the inspiration to survive. This may be attributable to the ability of SCs to help organizations meet the profound challenges they struggle with. In particular, the challenges for an organization are no longer restricted to performing its own operations effectively and efficiently; additionally, it must ensure that the manufacturers' and suppliers' operations are being performed appropriately, and it must build strong relationships with its customers. Such strategies are necessary to gauge an organization's progress toward achieving a competitive advantage and ensuring the sustainability of its operations by building solid relationships with its customers, manufacturers, and suppliers, which is the logic behind SCs. However, the UK experience is that a SC, especially in the retail sector, "is more likely to be a center of conflict and acrimony than harmonious cooperation" (Duke, 1998:99).

The SC is the starting point for this network. In the Problematization phase, actors who make up this network should be identified (the interdefinition of actors, according to ANT language). The nature of a SC brings specific actors into the network: big retailers; suppliers and manufacturers; customers; employees; government; unions; pressure groups; academics; and media.

Retailers, suppliers and manufacturers, and customers are the building blocks of any retail SC. It is clear that to achieve a competitive advantage in today's business market, establishing ongoing relationships with other actors throughout the SC is required (Fernie et al., 2010). So, retailers, suppliers, and manufacturers are interested in contributing to this network. Customers, also, are interested in assessing the effects of SC relationships on the value of the product or service received.

In addition, SC practices have substantial effects on the workforce, as the staff who are engaged in these practices need to be equipped with the necessary skills and behavioral flexibility (Scarbrough, 200o). Indeed, as employees bear the burden of reducing overall SC costs, they are interested in knowing the implications of SC practices for the company policies and their rights. This brings another actor directly into the network, namely, the unions, which are responsible for defending the rights of their members. Furthermore, the government, pressure groups, media, and academics are also interested in identifying and assessing the implications of SC practices on the efficiency of the market.

Competition and cooperation within the SC result in creating a highly sophisticated institutional context within which some actors strive to control other actors for their own competencies (Petrovic \& Hamilton, 2011). Thus, the question that concerns all actors in this network is regarding the outcomes of SC practices and whether or not these practices can yield equal benefits 
to SC participants and the market. Therefore, the outcomes of SC practices can be regarded as the obligatory passage point.

Once the actors in the network have been identified and defined, interessement is needed, as the alignment is still only loosely coupled. Actions are required to stabilize the identity of the actors identified during the problematization phase. Indeed, the construction of the SC itself is a valid interessement device for some actors; however, other actors may not have the same interest in engaging in the network's activities. Therefore, additional interessement devices are necessary.

Notions such as SC management, sustainable SC, and green SC motivate some pressure groups who are concerned with the environment and society, academics from various areas of research, and the media to participate in the network. In addition, the SC idea has been disseminated through conferences, seminars, articles, and reports, and so it has attracted different actors. These devices seek to engage actors more closely with the network. Then, enrolment is required to satisfy the actual alignment of the network.

According to Munir and Jones (2004:572), "Actors are enrolled by persuading them, and giving incentives to them, to become stakeholders." In other words, trade-offs are made to create room for maneuver during the negotiations. Manufacturers, suppliers, retailers, customers, and employees are expected to acquire new knowledge and receive financial incentives, such as a higher profit margin, cost savings, higher salaries, and so on, from enrolling in the SC. Knowledge is the key incentive for pressure groups, academics, and the media to join the SC network, as they can use the acquired knowledge for their own reuse and benefit. The quest to protect some actors in the market through issuing inscriptions, such as new acts and regulations, is the prominent incentive for governments and unions to enroll in the SC network. So, the enrolment process seeks to attach actors to the propositions and promises of the SC to stabilize the network and, thus, draw up the power of the SC (Mouritsen, 2007). Then, the mobilization process determines whether the commitments of the SC are sustained (Knights, Murray, \& Willmott, 1993).

The SC concept shows that changes are required in the business mindset, including the adoption of advanced information systems to control the SC, while SC partners have to synergize their strength to enhance SC efficiency by establishing ongoing relationships and information sharing and by integrating environmental concerns into SC activities (Fernie et al., 2010; Jones, Hillier, \& Comfort, 2013; Ytterhus, Arnestad, \& Lothe, 1999). Point-of-sale technology, electronic data interchange, vendor-managed inventory, open-book accounting, and value chain analysis are the intermediaries that help SC partners to comply with SC requirements (Dekker, 2003; Free, 2008; Hamilton \& Petrovic, 2011), and some actors have become actively involved in these changes and developments.

Big retailers have led the way in adopting advanced technologies and information systems and, thus, driving the diffusion of technologies amongst their partners (i.e., manufacturers and suppliers) (Hamilton \& Petrovic, 2011). Armed with information generated from these systems on consumer buying habits, retailers have been able to reduce stock levels and working capital requirements, refine the marketing mix, and help manufacturers to plan their production schedule (Duke, 1998; L. C. Harris \& Ogbonna, 2001; Jones, Comfort, Hillier, et al., 2005a; Ogbonna \& Wilkinson, 1998). They also utilize an open-book costing technique with their suppliers to reduce costs (Blythman, 2004).

The government also has been involved by establishing a code of practice to govern SC relationships; this facilitates mutually beneficial arrangements between big retailers and their suppliers (Fearne, Duffy, \& Hornibrook, 2005; Hollingsworth, 2004). SC challenges and requirements have attracted researchers and academics from various areas, including production management, marketing, information technology, project management, engineering, accounting, etc. Many articles have been published regarding SCs within the UK retail market. Pressure groups and media have pushed specific environmental issues (e.g., energy and water consumption, recycling, etc.) that should be considered along with the SC and have tried to increase customers' awareness regarding consuming in environment-friendly ways (F. Harris \& O'Brien, 1993). Consequently, in addition to price and quality, customers have begun to care more about health and environmental issues and so 
have started to ask for safe and healthy food from their food retailers (Kotzab, Munch, Faultrier, \& Teller, 2011; Ytterhus et al., 1999).

Big retailers and their partners have responded to the pressure from customers, the media, pressure groups, and the government by developing many environmentally responsive policies (Jones, Comfort, \& Hillier, 2007; Jones, Comfort, Hillier, \& Eastwood, 2005b; Jones, Hillier, Comfort, \& Eastwood, 2005; Kotzab et al., 2011; Strong, 1995). Thus, they have introduced environmental screening processes, including putting additional criteria into the retailer's purchasing policy, using a life-cycle assessment to assess products' environmental impact, and evaluating suppliers' environmental policies (Ytterhus et al., 1999). They have also developed and reported on Corporate Social Responsibility (CSR) Key Performance Indicators (KPIs) to benchmark their performance with industry standards and government targets (Jones, Comfort, \& Hillier, 2005; Jones, Comfort, Hillier, et al., 2005b). In addition to providing researchers with different ways to analyze their environmental policies, big retailers are using different forms of inscriptions (e.g., contrived advertisements, information pamphlets, press releases, CSR reports, etc.) to make sure that customers and the public are fully aware of their commitments regarding the environment (F. Harris \& O'Brien, 1993).

As well as management being concerned with the SC, employees are engaging in implementing SC strategies and sharing their ideas with their leaders on how to enhance SC efficiency. Labour unions send their representatives to the companies to ensure they fulfill their commitments to their employees, and big retailers always report their commitments to their labor and the attractive benefits they provide, including wages, training, profit sharing, health and safety, and pensions ( $F$. Harris \& O'Brien, 1993).

The previous discussion shows that suppliers and manufacturers are not sufficiently involved in the network. The problem lies in the workability of the changes required by SC:

It is easy to talk in general terms about the principles of partnership, but their application in practice - the "how" of using the exchange of information to achieve the benefits, is a problem... Despite an increasing general willingness to work together there remain many attitudes, prejudices, corporate cultures to be changed and hidden agendas to be exposed if we are to explore the full range of possibilities. (Zairi, 1998:61)

The power balance in the UK retail market is noticeably asymmetrical due to the centralization of the buying power and market concentration. Manufacturers and suppliers believe that big retailers use information systems and information sharing techniques, such as open-book accounting, to benefit only themselves and to drive down prices (Blythman, 2004; Duke, 1998; Harvey, 2000; Ogbonna, 1989; Towill, 2005). This mistrust is a preeminent force driving suppliers, manufacturers, and big retailers towards distributive approaches rather than the integrative ones required by SCs (Duke, 1998). In addition, suppliers and manufacturers believe that big retailers are transferring customers' pressure on price, quality, and environment onto them, so that not all SC partners can receive equal benefits as had been promised (Dixon \& Marston, 2005). The question is whether the British government can help in solving this dilemma.

Regarding SC relationships, Seth and Randall (2011:189) comment, "It is also well beyond any government's capabilities to arbitrate or to create a set of procedures that will make everyone happy". However, while the government tries to define the relationships between SC partners, the government's power to influence the retail market is limited due to its institutional complexity (Petrovic \& Hamilton, 2011). All these factors, as well as increasing levels of market concentration, have also enabled big retailers to control the retail market and to become the representatives not only of retailers, but also of the SC itself (Hollingsworth, 2004). "Successful 'translation' happens when actors accept their roles; translation fails when it cannot overcome heterogeneous preferences and motivations" (Dedeurwaerdere, Stromberg, \& Pascual, 2012:115). Therefore, a revision of the interessement, enrolment, mobilization phases may be required for this network until it stabilizes. 


\subsection{Globalization - Based Network}

Globalization may not be an elegant word, but it is a portmanteau term that no one can ignore (Giddens, 2002; Jacobs, 2001). According to Giddens (2002:7), "It has come from nowhere to be almost everywhere", while Arnason (1990:220) comments that "globalization in the first and broadest sense is best defined as the crystallization of the entire world as a single place and as the emergence of a global-human condition." Another definition, from the Stanford Encyclopaedia of Philosophy, describes globalization as (Bhimani \& Bromwich, 2009:87):

Fundamental changes in the spatial and temporal contours of social existence, according to which the significance of space or territory undergoes shifts in the face of a no less dramatic acceleration in the temporal structure of crucial forms of human activity.

It is wrong to think of globalization solely from an economic perspective; it should be regarded as a multidimensional process, which unfolds simultaneously in various realms of existence (Pieterse, 1995). Thus, "globalization may be understood in terms of an open-ended synthesis of several disciplinary approaches. This extends beyond social science, for instance to ecological concerns, technology and agricultural techniques" (Pieterse, 1995:45).

Accordingly, globalization may influence the UK retail markets - but in what way?

Problematization phase. The multifaceted nature of globalization has attracted various actors who are interested in its meaning and impacts and who may be expected to play some role in determining its future ramifications. These actors include big retailers, customers, overseas markets, the media, ethnic minority-owned business enterprises, and governments and regulatory authorities.

a. Big retailers: The UK big retailers are inclined towards global markets to deliver better costs and pricing to their customers and to create new customer markets (Seth \& Randall, 2011).

b. Customers: They are one of the beneficiaries of globalization. They benefit from low prices and increased product availability and quality due to the involvement of big retailers in global activities. In addition, the growth in globalization, migration, and tourism has led to the creation of large ethnic customer groups in the UK, which are characterized by a strong cultural identity (Jamal, 2003).

c. Ethnic minority-owned business enterprises: They emerged in response to the existence of large ethnic minority populations in the UK. They focus on customers of a particular ethnicity, as they are characterized by a strong ethnic identity and informal networks based on mutual trust and reputation (Jamal, 2003).

d. Overseas markets: Globalization has pushed the UK big retailers to go abroad to create new supplier and consumer markets to maximize their leverage (Hamilton \& Petrovic, 2011). These markets provide the big retailers with goods to be sold to their customers and open their doors to retailers to invest and grow within these markets.

e. Media: media coverage has promoted greater interest in globalization by different actors, such as customers, big retailers, and so on.

f. Governments and regulatory authorities: The nature of globalization has forced the involvement of different governmental and regulatory regimes with different agendas about globalization, which the UK big retailers have to adhere to when engaging in global activities (Jones, Comfort, \& Hillier, 2004).

The common thread for all these actors is gaining a deep understanding of the outcomes of globalization, which can be regarded as the obligatory passage point.

Interessement phase. Globalization is a relevant interessement device for actors to engage and participate in the network's activities. Other interessement devices include television programs, newspapers, magazines, and conferences, which help in disseminating the idea among actors and preparing them to engage in the network.

Enrolment phase. Globalization is expected to offer attractive benefits to all actors involved in the network. Big retailers, customers, ethnic minority-owned business enterprises, and overseas markets are expected to get economic benefits, such as lower prices, higher profit margins, and 
higher sales from engaging in this network. Enrolling in this network enables the media, governments, and regulatory authorities to acquire the necessary knowledge and to then reuse it in increasing other actors' awareness and issuing rules and regulations to protect other actors.

The final phase is mobilization. Globalization has indicated mechanisms by which global activities are achieved in the retail market, which include the international sourcing of products or services; the operation of retail outlets in more than one country; and the transfer of ideas, technologies, and management techniques and expertise from one retailer to another (J. A. Dawson, 1993).

International sourcing is rapidly becoming a prerequisite for successful UK retailers. Price, variety, quality, and product availability are among the factors that create the need to source internationally (J. A. Dawson, 1993). International sourcing has been facilitated by the deployment of advanced technologies (e.g., EDI, computer-aided systems, etc.), better standards of information sharing (e.g., open-book accounting, inter-organizational cost management, joint target costing, etc.), and advanced production planning and inventory control systems, along with the development of important supporting actors, including shipping, warehousing operations, air freight companies, and so on (Bonacich \& Hamilton, 2011; J. A. Dawson, 1993; Sturgeon, Humphrey, \& Gereffi, 2011).

In response to international sourcing, overseas markets, especially East Asian economies, have started to diverge by increasing the variety and quality of products produced to become suppliers to big retailers (Bonacich \& Hamilton, 2011).

Contemporary customers are open and have the propensity to experience new things, especially with the increasing media coverage of foreign foodstuffs and international recipes, which has encouraged more customers to sample a variety of different kinds of cuisines (Jamal, 2003; Jones et al., 2004). Furthermore, the presence of a growing number of ethnic minority customers in the UK has helped in developing the preferences of mainstream customers, which, in turn, has generated the need for big UK retailers to engage in international sourcing to carry ethnic merchandise and has opened new opportunities for ethnic minority-owned business enterprises outside their ethnic niche (Jamal, 2003).

Regarding the increase in ethnic minority customers, governments, regulatory authorities, and international organizations have helped in reducing the barriers to global sourcing through reducing tariffs and quotas and through the formation of international organizations and associations (e.g., European Community's Single Market, World Trade Organization, etc.) that facilitate international trade (J. A. Dawson, 1993).

Similarly, the limited expansion opportunities in the UK market due to the restrictive regulatory environment, market saturation, and unlimited opportunities in global markets have led the UK big retailers to pursue a strategy of 'going international' (Alexander, 1995; Arnold \& Fernie, 2000). The UK big retailers are particularly inclined toward European, North American, and East Asian markets (Alexander, 1995; L. C. Harris \& Ogbonna, 2001; Myers \& Alexander, 1996). However, the development of advanced communication medium has also spurred the retailers to expand into global markets to cater to the customers of these countries and open up new business avenues (Doherty, EllisChadwick, \& Hart, 2003). In addition, the UK big retailers have engaged in franchising operations, which are perceived as a low cost and low risk alternative to achieve rapid international market penetration (Alexander \& Quinn, 2002; Elms et al., 2010). Franchisors provide franchisees with the expertise and continual support required to run the business, and franchisees are expected to provide the franchisor with financial capital as well as managerial talent, local market knowledge, and other human capital (Watson, Stanworth, Healeas, Purdy, \& Stanworth, 2005).

The third main route of retail globalization is the transfer of human capital, formats, and technologies (J. A. Dawson, 1993). Many UK big retailers are following and matching the US ones in size, formats, technologies, and so on. Indeed, the managers of many UK retailers (e.g., Tesco, Asda, etc.) are traveling to the USA to tap into and gain access to the expertise of the most advanced economy in the world (Wortmann, 2011).

It can be seen from the previous discussion that globalization can bring many benefits to 
retailers, customers, overseas markets, and so on; however, some problems have started to arise, including the following:

- An increasing level of UK retailers' withdrawals from the foreign market has occurred due to a failure to appreciate the cultural differences and nature of competition in these markets (Alexander \& Quinn, 2002).

- Sourcing foodstuffs within the global marketplace has led to growing customer and public concerns about food safety and health issues. The UK big retailers have started to report on their commitments regarding food safety in their CSR reports (Jones, Comfort, \& Hillier, 2005; Jones, Comfort, Hillier, et al., 2005a).

- The existence of different political and regulatory regimes between and across countries has made the issue of ethical trading more complex for UK retailers (Jones, Comfort, \& Hillier, 2005).

- The mistrust between franchisors and franchisees affects the willingness of franchisees to share their own innovations, as they will reap no direct benefit (Watson et al., 2005). This, in turn, can affect the efficiency of franchising operations.

All these issues need to be resolved before this network can be a 'black box'.

\section{Discussion \& Conclusion}

Globalization, rapid technological advancement, and the emergence of new forms of organizations have increased the complexity of the retail markets and led to the enrolment of various social and technical actors in the market that interact together and with other human actors, to form the market as we know it today. Due to such complexity, the separation between human and non-human actors has been undermined. ANT can fit well with this ideology as it supports treating both human and non-human actors symmetrically and rejects any priori that either human or non-human actors affect the actions of the other (Latour, 2005). Drawing upon ANT, this paper focused on studying how the UK retail market networks are constructed and mobilized. I utilized the notion of 'translation', which consists of four phases (problematization, interessement, enrolment, and mobilization) to explore what encourages actors to enroll in a network, how they interact and negotiate, and the nature of the concerns that can be raised by those actors.

From the literature, I found that there are three major networks within the UK retail sector: market concentration-based network, supply chain-based network, and globalization-based network. The paper shows that the reasons behind initiating each network are different. For instance, the concentration of the UK retail market in the hands of a few actors was the reason for bringing various actors together to form the market concentration-based network, while the multifaceted nature of globalization and its consequences was the driving force behind initiating a globalizationbased network. This, in turn, affected the type of actors who joined and engaged in each network. Big retailing chains, suppliers and manufacturers, customers, government and regulatory authorities, politicians, academics, the media, and pressure groups are the actors who showed their interest in joining a market concentration-based network. Big retailers, suppliers and manufacturers, customers, employees, government, unions, pressure groups, academics, and media engaged in a supply chainbased network. The actors who enrolled in globalization-based network were big retailers, customers, overseas markets, the media, ethnic minority-owned business enterprises, and Government and regulatory authorities.

Some of the actors were enrolled in more than one network, such as big retailing chains, suppliers and manufacturers, government, media, and so on; however, what encourages each of these actors to join a network is different. For example, while the government engaged in a market concentration-based network to protect actors from any possible competitive threat that can result from market concentration, it participated in a globalization-based network to set the guidelines to which the actors have to adhere when engaging in global activities. Therefore, each network is 
constituted by a set of heterogeneous actors with diverse interests and objectives.

The obligatory passage point for actors in each network was identified in the problematization phase. Assessing the consequences of market concentration, determining the outcomes of SC practices and whether they can yield equal benefits to SC actors, and evaluating the outcomes of globalization are regarded as the obligatory passage point for the three networks, respectively. Identifying the obligatory passage point helped articulate the actors' commitment to the network in which they were interested.

It can be noted that intermediaries play a vital role in linking the actors enrolled in the UK retail market networks. Accounting (in terms of annual reports and management accounting techniques, such as open-book accounting, inter-organizational cost management, PM systems, and KPIs), advanced technologies (e.g., EPOS, EDI, etc.), and money are the language of the three networks, as they provide the links that connect the actors together. Also, various interessement devices had been used to engage actors more closely in the activities of each network. These devices included conferences, seminars, meetings, workshops, TV programs, articles, and so on. The use of different devices can be attributed to the diverse interests and needs of actors in each network.

The literature showed that there are some issues and challenges that actors face while constructing the network. One of these issues is the mistrust between retailers and suppliers. Suppliers believe that big retailers are pushing their costs back onto them and that they use information sharing techniques to benefit only themselves. Another issue is related to retail policy making in the UK. The literature showed that there were inconsistencies with regard to the policies that guide the UK retailing sector. For instance, the town planning system puts restrictions on the development of large supermarkets, while other departments that deal with competition encourage the development of large stores. Other concerns include reducing the number of small shops, health and environmental issues, cultural differences, etc. These concerns are still disputable and open for debate between actors, which, in turn, affect the mobilization of the three networks.

Elaboration of the 'translation' process has identified the power relations that empower big UK retailers to exercise control over the market. According to Latour (1986a:264):

When an actor simply has power, nothing happens and s/he is powerless; when, on the other hand, an actor exerts power, it is others who perform the action. It appears that is not something one can possess - indeed, it must be treated as a consequence rather than as a cause of action.

This means that actors' actions within the networks are what give rise to the power position. The literature showed that many actors could accept the views of big retailers even if they are not convinced to achieve their long-term objectives. For instance, although suppliers believe that big retailers sometimes behave opportunistically, many suppliers are prepared to accept this to keep their relationships with big retailers to survive in this complex market. Also, a town planning authority can permit big retailers to open large stores if they fund some activities, although current planning policies are regarded as a virtual ban on the development of big supermarkets.

The interrelationships between the three networks also give rise to this power. The concentration of the market in the hands of a few powerful retailers, reinforced by globalization and the 'going international' strategy, has enabled these retailers to control the SC (Arnold \& Fernie, 200o). Engaging in SC practices has reinforced the power position at the retailer end of the chain and increased market concentration (Fernie et al., 2010). In addition, the continuing advances in global practices have enabled the big retailers involved in these practices to control their SCs.

In conclusion, this paper provided another way of conceiving the UK retail sector's complexity through an ANT lens. It showed that the UK retail market consists of a set of networks of heterogeneous human and non-human actors interacting together to form this market. It also showed that these networks are still unstable as many issues have not been solved yet, and that power is an outcome of the actors' actions within the networks and interrelationships between networks.

The analysis in this paper is derived from reviewing academic papers and books. This was helpful for me to understand the dynamics of this market, its key actors, and its challenges before 
going to the fieldwork to collect my data. However, focusing on academic literature only implies restrictions and problems. Professional studies, governmental reports, media pieces, and so on, that could be highly relevant are not considered, limiting the analysis's depth. It can also lead to missing some critical areas that can affect the analysis. For instance, there is no mention of setting up the UK's Groceries Code Adjudicator, although it plays a vital role in monitoring the relationships between retailers and their suppliers. Therefore, future reviews can include professional papers and other sources to extend this review.

Also, the analysis is based on reviewing the literature from different times (1990s - 200os). However, it is questioned how relevant older publications are today, especially as we are talking about a sector that is characterized by rapid change. This can have repercussions on the researcher's understanding of the network structure if the researcher is not a citizen or permanent resident of the country in which s/he is conducting her/his research (like my case). It is always suitable to account for older sources, but it can have drawbacks.

Any literature review is selective by nature and can't cover all aspects. This literature didn't cover some areas such as marketing and geography. Therefore, future reviews are welcomed to cover these aspects.

\section{Acknowledgment}

The author would like to acknowledge the support of Prince Sultan University for their support.

\section{References}

Alcadipani, R., \& Hassard, J. (2010). Actor-Network Theory, organizations and critique: towards a politics of organizing. Organization, 17(4), 419-435. doi:10.1177/1350508410364441

Alcouffe, S., Berland, N., \& Levant, Y. (2008). Actor-networks and the diffusion of management accounting innovations: A comparative study. Management Accounting Research, 19(1), 1-17. doi:http://dx.doi.org/10.1016 /j.mar.2007.04.001

Alexander, N. (1995). UK retail expansion in North America and Europe A strategic dilemma. Journal of Retailing and Consumer Services, 2(2), 75-81. doi:http://dx.doi.org/10.1016/o969-6989(95)ooo26-7

Alexander, N., \& Quinn, B. (2002). International retail divestment. International Journal of Retail E Distribution Management, 30(2), 112-125.

Allan, J. (1980). The changing retail pattern. International Journal of Retail E Distribution Management, 8(4), 21-26.

Arnason, J. P. (1990). Nationalism, globalization and modernity. In M. Featherstone (Ed.), Global culture: nationalism, globalization and modernity (pp. 207-236). London: SAGE Publications Ltd.

Arnold, S. J., \& Fernie, J. (200o). Wal-Mart in Europe: prospects for the UK. International Marketing Review, $17(4 / 5), 416-432$.

Bank, T. W. (2013). World Development Indicators, The World Bank. http://data.worldbank.org/datacatalog/GDP-ranking-table

Bapuji, H., Hora, M., \& Saeed, A. M. (2012). Intentions, Intermediaries, and Interaction: Examining the Emergence of Routines. Journal of Management Studies, 49(8), 1586-1607. doi:10.1111/j.1467-6486.2012.01063.x

Bevan, J. (2005). Trolley wars: the Battle of the Supermarkets. London: Profile Books Ltd.

Bhimani, A., \& Bromwich, M. (2009). Management Accounting in a Digital and Global Economy: The Interface of Strategy, Technology, and Cost Information. In C. S. CHAPMAN, D. J. COOPER, \& P. B. MILLER (Eds.), Accounting, Organizations, and Institutions (pp. 85-111). New York: Oxford University Press.

Blythman, J. (2004). Shopped: the shocking power of British supermarkets. London: Harper Perennial.

Bonacich, E., \& Hamilton, G. G. (2011). Global logistics, global labor. In G. G. Hamilton, M. Petrovic, \& B. Senauer (Eds.), The market makers: how retailers are reshaping the global economy (pp. 211-230). Oxford: Oxford University Press.

Brown, S. (1990). Innovation and Evolution in UK Retailing: The Retail Warehouse. European Journal of Marketing, 24(9), 39-54.

Burt, S., \& Sparks, L. (1994). Structural change in grocery retailing in Great Britain: a discount reorientation? The International Review of Retail, Distribution and Consumer Research, 4(2), $195-217$. doi:10.108o/o95939694000ooo16 
Burt, S., \& Sparks, L. (1995). Understanding the arrival of limited line discount stores in Britain. European Management Journal, 13(1), 110-119. doi:http://dx.doi.org/10.1016/0263-2373(94)ooo63-D

Burt, S., Sparks, L., \& Teller, C. (2010). Retailing in the United Kingdom - a Synopsis. European Retail Research, 24(1), 173-194. doi:10.1007/978-3-8349-8938-3_8

Callon, M. (1986). Some elements of a sociology of translation: domestication of the scallops and the fishermen of St Brieuc Bay. In J. Law (Ed.), Power, action and belief: a new sociology of knowledge? (pp. 196-233). London: Routledge \& Kegan Paul plc.

Callon, M. (1991). Techno-economic networks and irreversibility. In J. Law (Ed.), A sociology of monsters: essays on power, technology and domination (pp. 132-161). London: Routledge.

Callon, M. (1993). Variety and irreversibility in networks of technique conception and adoption. In D. Foray \& C. Freeman (Eds.), Technology and the wealth of nations: the dynamics of constructed advantage (pp. 232-268). London: Pinter.

Callon, M. (1999). Actor-network theory - the market test. In J. Law \& J. Hassard (Eds.), Actor network theory and after (pp. 181-195). Oxford: Blackwell Publishers.

Callon, M., \& Latour, B. (1981). Unscrewing the big Leviathan: how actors macrostructure reality and how sociologists help them do so. In K. Knorr-Cetina \& A. V. Cicourel (Eds.), Advances in Social Theory and Methodology: Toward an Integration of Micro- and Macro-Sociologies (pp. 277-303). London: Routledge \& Kegan Paul.

Clarke, I. (2000). Retail power, competition and local consumer choice in the UK grocery sector. European Journal of Marketing, 34(8), 975 - 1002.

Comber, A., Fisher, P., \& Wadsworth, R. (2003). Actor-network theory: a suitable framework to understand how land cover mapping projects develop? Land Use Policy, 2o(4), 299-309. doi:http://dx.doi.org/10.1016/So2648377(03)00048-6

Consortium, B. R. (2012). UK Retail: Leading Globally, Serving Locally (pp. 1-47): Oxford Economics \& Oxford Institute of Retail Management.

Craven, B. M., \& Marston, C. L. (1999). Financial reporting on the internet by leading UK companies. European Accounting Review, 8(2), 321-333. doi:10.1080/096381899336069

Dawson, J. (2004). Food retailing, wholesaling and catering. In M. A. Bourlakis \& P. W. H. Weightman (Eds.), Food Supply Chain Management (pp. 116-135). Oxford: Blackwell Publishing Ltd.

Dawson, J. A. (1993). The internationalization of retailing. In R. D. F. Bromley \& C. J. Thomas (Eds.), Retail change: contemporary issues (pp. 15-40). London: UCL Press Limited.

De Kervenoael, R., Hallsworth, A., \& Clarke, I. (2006). Macro-level change and micro level effects: A twenty-year perspective on changing grocery shopping behaviour in Britain. Journal of Retailing and Consumer Services, 13(6), 381-392. doi:http://dx.doi.org/10.1016/j.jretconser.2006.02.003

Dedeurwaerdere, T., Stromberg, P. M., \& Pascual, U. (2012). Social Motivations and Incentives in Ex Situ Conservation of Microbial Genetic Resources. In M. D. d. Rosnay \& J. C. D. Martin (Eds.), The Digital Public Domain: Foundations for an Open Culture (pp. 111-124). Cambridge: Open Book Publishers.

Dekker, H. C. (2003). Value chain analysis in interfirm relationships: a field study. Management Accounting Research, 14(1), 1-23. doi:10.1016/s1044-5005(02)00067-7

Dixon, T., \& Marston, A. (2005). Taking the shopping centre online: new models in e-commerce. Property Management, 23(2), 97-109.

Doherty, N., Ellis-Chadwick, F., \& Hart, C. (2003). An analysis of the factors affecting the adoption of the internet in the UK retail sector. Journal of Business Research, 56(11), 887-897. doi:http://dx.doi.org/10.1016/So1482963(01)00275-2

Doolin, B., \& Lowe, A. (2002). To reveal is to critique: actor-network theory and critical information systems research. Journal of Information Technology (Routledge, Ltd.), 17(2), 69-78. doi:10.1080/02683960210145986

Duke, R. (1998). A model of buyer-supplier interaction in UK grocery retailing. Journal of Retailing and Consumer Services, 5(2), 93-103. doi:http://dx.doi.org/10.1016/So969-6989(97)ooo64-7

Ellis-Chadwick, F., Doherty, N. F., \& Anastasakis, L. (2007). E-strategy in the UK retail grocery sector: a resourcebased analysis. Managing Service Quality, 17(6), 702-727.

Elms, J., Canning, C., Kervenoael, R. d., Whysall, P., \& Hallsworth, A. (2010). 30 years of retail change: where (and how) do you shop? International Journal of Retail $\mathcal{E}$ Distribution Management, 38(11/12), 817-827.

Ezzamel, M. (1994). Organizational Change and Accounting: Understanding the Budgeting System in its Organizational Context. Organization Studies, 15(2), 213-240. doi:10.1177/017084069401500203

Fearne, A., Duffy, R., \& Hornibrook, S. (2005). Justice in UK supermarket buyer-supplier relationships: an empirical analysis. International Journal of Retail E Distribution Management, 33(8), 570 - 582. 
Fernie, J., Sparks, L., \& McKinnon, A. C. (2010). Retail logistics in the UK: past, present and future. International Journal of Retail E Distribution Management, 38(11/12), 894-914.

Frances, J., \& Garnsey, E. (1996). Supermarkets and suppliers in the United Kingdom: System integration, information and control. Accounting, Organizations and Society, 21(6), 591-610. doi:10.1016/03613682(96)oooo1-3

Free, C. (2008). Walking the talk? Supply chain accounting and trust among UK supermarkets and suppliers. Accounting, Organizations and Society, 33(6), 629-662. doi:10.1016/j.aos.2007.09.001

Gardner, C., \& Sheppard, J. (1989). Consuming passion: the rise of retail culture. London: Unwin Hyman Limited.

Giddens, A. (2002). Runaway world: how globalization is reshaping our lives. London: Profile Books Ltd.

Guy, C. (1995). Retail store development at the margin. Journal of Retailing and Consumer Services, $2(1), 25-32$. doi:http://dx.doi.org/10.1016/o969-6989(95)ooo3o-5

Guy, C. (1998a). Classifications of retail stores and shopping centres: some methodological issues. GeoJournal, 45(4), 255-264. doi:10.1023/A:1006960414161

Guy, C. (1998b). Off-Centre Retailing in the UK: Prospects for the Future and the Implications for Town Centres. Built Environment (1978-), 24(1), 16-30. doi:10.2307/23287827

Guy, C., \& Bennison, D. (2002). Retail planning policy, superstore development and retailer competition. International Journal of Retail E Distribution Management, 30(9), 431-434.

Hackney, R., Grant, K., \& Birtwistle, G. (2006). The UK grocery business: towards a sustainable model for virtual markets. International Journal of Retail E Distribution Management, 34(4/5), 354-368.

Hamilton, G. G., \& Petrovic, M. (2011). Introduction. In G. G. Hamilton, B. Senauer, \& M. Petrovic (Eds.), The market makers: how retailers are reshaping the global economy (pp. 1-29). Oxford: Oxford University Press.

Harris, F., \& O'Brien, L. (1993). The greening of shopping. In R. D. F. Bromley \& C. J. Thomas (Eds.), Retail change: contemporary issues (pp. 229-246). London: UCL Press Limited.

Harris, L. C., \& Ogbonna, E. (2001). Competitive advantage in the UK food retailing sector: past, present and future. Journal of Retailing and Consumer Services, 8(3), 157-173. doi:http://dx.doi.org/10.1016/So9696989(0o)oooo9-6

Harvey, M. (200o). Innovation and competition in UK supermarkets. Supply Chain Management: An International Journal, 5(1), 15-21.

Hollingsworth, A. (2004). Increasing retail concentration: Evidence from the UK food retail sector. British Food Journal, 106(8), 629-638.

Jacobs, M. (2001). The environment, modernity and the third way. In A. Giddens (Ed.), The global third way debate (pp. 317-339). Cambridge: Polity Press.

Jamal, A. (2003). Retailing in a multicultural world: the interplay of retailing, ethnic identity and consumption. Journal of Retailing and Consumer Services, 1o(1), 1-11. doi:http://dx.doi.org/10.1016/So969-6989(02)ooo59-o

Jones, P., Comfort, D., \& Hillier, D. (2004). A case study of local food and its routes to market in the UK. British Food Journal, 106(4), 328-335.

Jones, P., Comfort, D., \& Hillier, D. (2005). Corporate social responsibility and the UK's top ten retailers. International Journal of Retail E Distribution Management, 33(12), 882-892.

Jones, P., Comfort, D., \& Hillier, D. (2007). Marketing and corporate social responsibility within food stores. British Food Journal, 109(8), 582-593.

Jones, P., Comfort, D., Hillier, D., \& Eastwood, I. (2005a). Corporate social responsibility: a case study of the UK's leading food retailers. British Food Journal, 107(6), 423-435.

Jones, P., Comfort, D., Hillier, D., \& Eastwood, I. (2005b). Retailers and sustainable development in the UK. International Journal of Retail \& Distribution Management, 33(3), 207 - 214.

Jones, P., \& Hillier, D. (2000). Changing the balance - the "ins and outs" of retail development. Property Management, $18(2), 114-126$.

Jones, P., Hillier, D., \& Comfort, D. (2013). In the Public Eye: Sustainability and the UK's Leading Retailers. Journal of Public Affairs, 13(1), 33-40. doi:10.1002/pa.1440

Jones, P., Hillier, D., Comfort, D., \& Eastwood, I. (2005). Sustainable retailing and consumerism. Management Research News, 28(1), 34-44.

Knights, D., Murray, F., \& Willmott, H. (1993). Networking as knowledge work: a study of strategic interorganizational development in the financial services industry*. Journal of Management Studies, 3o(6), 975-995. doi:10.1111/j.1467-6486.1993.tboo475.x

Kotzab, H., Munch, H. M., Faultrier, B. d., \& Teller, C. (2011). Environmental retail supply chains: when global Goliaths become environmental Davids. International Journal of Retail E Distribution Management, 39(9), 658-681. 
Latour, B. (1987). Science in action: How to follow scientists and engineers through society. Cambridge: Harvard University Press.

Latour, B. (1993). We have never been modern. London: Harvester Wheatsheaf.

Latour, B. (2003). Is Re-modernization Occurring - And If So, How to Prove It?: A Commentary on Ulrich Beck. Theory, Culture E Society, 20(2), 35-48. doi:10.1177/0263276403020002002

Latour, B. (2005). Reassembling the social: an introduction to Actor-Network-Theory. New York: Oxford University Press Inc.

Law, J. (1991). Introduction: monsters, machines and sociotechnical relations. In J. Law (Ed.), A Sociology of Monsters: Essays on Power, Technology and Domination (pp. 1-23). London: Routledge.

Law, J. (1992). Notes on the theory of the actor-network: Ordering, strategy, and heterogeneity. Systems practice, 5(4), 379-393. doi:10.1007/BFo1059830

Lee, N., \& Hassard, J. (1999). Organization Unbound: Actor-Network Theory, Research Strategy and Institutional Flexibility. Organization, 6(3), 391-404. doi:10.1177/135050849963002

Mähring, M., Holmström, J., Keil, M., \& Montealegre, R. (2004). Trojan actor-networks and swift translation: Bringing actor-network theory to IT project escalation studies. Information Technology \& People, 17(2), 210 - 238.

McLean, C., \& Hassard, J. (2004). Symmetrical Absence/Symmetrical Absurdity: Critical Notes on the Production of Actor-Network Accounts. Journal of Management Studies, 41(3), 493-519. doi:10.1111/j.14676486.2004.00442.X

Morelli, C. (1997). Britain's Most Dynamic Sector? Competitive Advantage in Multiple Food Retailing. Business and Economic History, 26(2), 770-781.

Mouritsen, J. (2007). Intellectual capital and the choices towards the future. In C. Chaminade \& B. Catasús (Eds.), Intellectual Capital Revisited: Paradoxes in the Knowledge Intensive Organization (pp. 166-188). Cheltenham: Edward Elgar Publishing Limited.

Mulley, S. (2011). Migration Statistics - February 2011 (pp. 1-4). London: Institute for Public Policy Research.

Munir, K. A., \& Jones, M. (2004). Discontinuity and After: the Social Dynamics of Technology Evolution and Dominance. Organization Studies, 25(4), 561-581. doi:10.1177/0170840604040676

Murdoch, J. (1997). Inhuman/non-human/human: actor-network theory and the prospects for a nondualistic and symmetrical perspective on nature and society. Environment and Planning D: Society and Space, 15 (6), 731 - 756.

Murdoch, J., Marsden, T., \& Banks, J. (200o). Quality, Nature, and Embeddedness: Some Theoretical Considerations in the context of the Food Sector*. Economic Geography, 76(2), 107-125. doi:10.1111/j.19448287.200o.tboo136.x

Myers, H., \& Alexander, N. (1996). European food retailers' evaluation of global markets. International Journal of Retail E Distribution Management, 24(6), 34-43.

Ogbonna, E. (1989). Strategic Changes in UK Grocery Retailing. Management Decision, 27(6), 45-50.

Ogbonna, E., \& Wilkinson, B. (1998). Power relations in the UK grocery supply chain: Developments in the 1990 . Journal of Retailing and Consumer Services, 5(2), 77-86. doi:http://dx.doi.org/10.1016/So969-6989(97)oooo4-0

Pal, J., Bennison, D., Clarke, I., \& Byrom, J. (2001). Power, policy networks and planning: the involvement of major grocery retailers in the formulation of Planning Policy Guidance Note 6 since 1988. The International Review of Retail, Distribution and Consumer Research, 11(3), 225-246. doi:10.1080/09593960122876

Petrovic, M., \& Hamilton, G. G. (2011). Retailers as market makers. In G. G. Hamilton, B. Senauer, \& M. Petrovic (Eds.), The market makers: how retailers are reshaping the global economy (pp. 31-49). Oxford: Oxford University Press.

Pieterse, J. N. (1995). Globalization as hybridization. In M. Featherstone, S. Lash, \& R. Robertson (Eds.), Global modernities (pp. 45-68). London: SAGE Publications Ltd.

Powell, J. L., \& Owen, T. (2011). Actor Network Theory and Social Science: possibilities and implications. Journal of Public Administration and Governance, 1(2), 140-157.

Rodger, K., Moore, S. A., \& Newsome, D. (2009). WILDLIFE TOURISM, SCIENCE AND ACTOR NETWORK THEORY. Annals of Tourism Research, 36(4), 645-666. doi:http://dx.doi.org/10.1016/j.annals.2009.06.001

Sarker, S., Sarker, S., \& Sidorova, A. (2006). Understanding Business Process Change Failure: An Actor-Network Perspective. Journal of Management Information Systems, 23(1), 51-86. doi:10.2307/40398827

Scarbrough, H. (200o). The HR implications of supply chain relationships. Human Resource Management Journal, 10(1), 5-17. doi:10.1111/j.1748-8583.200o.tbooo10.x

Serres, M. (1974). La Traduction: Hermès III. Paris: Éditions de Minuit.

Seth, A., \& Randall, G. (1999). The grocers: the rise and rise of the supermarket chains. London: Kogan Page Limited.

Seth, A., \& Randall, G. (2011). The grocers: the rise and rise of the supermarket chains. London: Kogan Page Limited. Size of ethnic groups: ONS estimates, 2009. (2009). Retrieved from http://www.ethnicity.ac.uk/population/size.html 
Statistics, O. f. N. (2013). Annual Mid-year Population Estimates, 2011 and 2012. London: Office for National Statistics Retrieved from http://www.ons.gov.uk/ons/rel/pop-estimate/population-estimates-for-uk-england-and-wales--scotland-and-northern-ireland/mid-2011-and-mid-2012/stb---mid-2011---mid-2012-ukpopulation-estimates.html.

Strong, C. (1995). The response of the UK's eight largest grocery retail organizations to growing environmental concern. Journal of Consumer Studies \& Home Economics, 19(2), 105-117. doi:10.1111/j.1470-6431.1995.tboo536.x

Strong, C. (1996). Features contributing to the growth of ethical consumerism - a preliminary investigation. Marketing Intelligence \& Planning, 14(5), 5-13.

Sturgeon, T., Humphrey, J., \& Gereffi, G. (2011). Making the global supply base. In G. G. Hamilton, M. Petrovic, \& B. Senauer (Eds.), The market makers: how retailers are reshaping the global economy (pp. 231-254). Oxford: Oxford University Press.

Thomas, A. B. (1991). Leadership and Change in British Retailing 1955-84. The Service Industries Journal, 11(3), 381392. doi:10.1080/02642069100000052

Towill, D. R. (2005). A Perspective on UK Supermarket Pressures on the Supply Chain. European Management Journal, 23(4), 426-438. doi:http://dx.doi.org/10.1016/j.emj.2005.06.0o6

Usherwood, B. (2000). Mrs housewife and her Grocer': the advent of self-service food shopping in Britain. In M. Andrews \& M. M. Talbot (Eds.), All the world and her husband: women in twentieth-century consumer culture (pp. 113-130). New York: Cassell.

Watson, A., Stanworth, J., Healeas, S., Purdy, D., \& Stanworth, C. (2005). Retail franchising: an intellectual capital perspective. Journal of Retailing and Consumer Services, 12(1), 25-34. doi:http://dx.doi.org/10.1016/j.jretconser .2004 .02 .001

Williams-Jones, B., \& Graham, J. E. (2003). Actor-Network Theory: a tool to support ethical analysis of commercial genetic testing. New Genetics and Society, 22(3), 271-296. doi:10.1080/1463677032000147225

Wortmann, M. (2011). Globalization of European retailing. In G. G. Hamilton, M. Petrovic, \& B. Senauer (Eds.), The market makers: how retailers are reshaping the global economy (pp. 118-154). Oxford: Oxford University Press.

Wrigley, N. (1992). Antitrust regulation and the restructuring of grocery retailing in Britain and the USA. Environment and Planning A, 24(5), 727 - 749 .

Wrigley, N. (1993). Retail concentration and the internationalization of British gocery retailing. In R. D. F. Bromley \& C. J. Thomas (Eds.), Retail change: contemporary issues (pp. 41-68). London: UCL Press.

Wrigley, N. (1998). PPG6 and the contemporary UK food store development dynamic. British Food Journal, 1oo(3), 154-161.

Ytterhus, B. E., Arnestad, P., \& Lothe, S. (1999). Environmental initiatives in the retailing sector: an analysis of supply chain pressures and partnerships. Eco-Management and Auditing, 6(4), $181-188$. doi:10.1002/(SICI)1099-0925(199912)6:4<181::AID-EMA115>3.0.CO;2-1

Zairi, M. (1992). The art of benchmarking: using customer feedback to establish a performance gap. Total Quality Management, 3(2), 177-188. doi:10.1080/09544129200000019

Zairi, M. (1998). Best practice in supply chain management: the experience of the retail sector. European Journal of Innovation Management, 1(2), 59 - 66. 